\title{
Surfing the wave
}

\section{プラズモンがひらく光技術の新時代}

Joerg Heber

Nature Vol. 461(720-722)/8 October 2009

金属表面の電子が集団で細かく振動するプラズモンは、光をナノスケールで操作することを可能にし、高速なコンピューター チップからがんの治療まで、広範な分野への応用が期待されている。

静かな池に小石を投げ込むと、水面にさ ざ波が広がっていく。金属の表面に光子 が衝突するときにも、これによく似たこと が起こる。ただし、その「さざ波」は集 団で振動する電子からなり、その波長は わずか数ナノメートルである。この振動は 「表面プラズモン」とよばれ、ひとたび発 生すると、より多くの光を集めて、金属表 面に沿ってかなり長い距離を伝播させるこ とができる。大阪大学の物理学者河田聡 は、この現象を学生に説明するときに「光 の川」という言葉を使う。

プラズモンはまた、極小の点に光を集 中させたり、複雑な回路に沿って光を導 いたりして、さまざまな方法で光を操作 することができる。これらの操作はすべて ナノスケールで行われる。これは光の波 長よりも数桁小さいスケールであり、従 来の光学装置の解像限界よりもはるかに 小さい。

その結果、プラズモニクスは今日のフォ トニクスの中で最も注目を集める分野の 1 つになっており、研究者たちは、太陽電池、 生化学センサー、光学コンピューターやが んの治療への応用を考えている $(20$ ペー ジコラム「プラズモンの応用」を参照)。

ナノテクノロジーとプラズモン

プラズモニクスの応用を支えているのは、 10 年ほど前からさかんになってきたナノ テクノロジーである。ナノテクノロジーの さまざまな技術が、プラズモニクスの実用 化に必要なナノスケールの構造を製作する

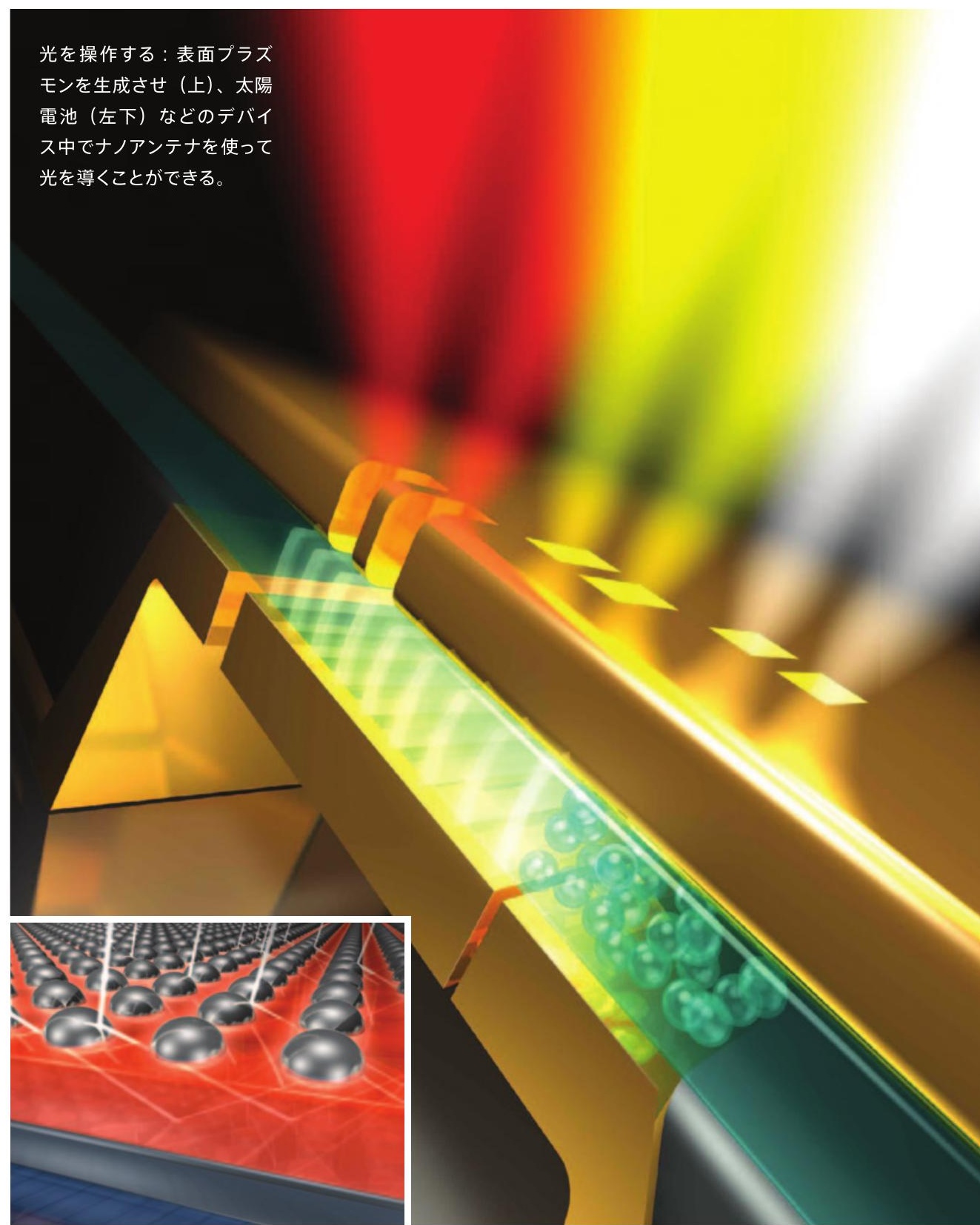


やつくばの NEC 筑波研究所などは、ディ スプレーや遠距離通信のためのプラズモ ン増強効果を利用したデバイスの試作に 取り組んでいる。

ホールアレイを利用して、光を光学デバ イスの中に導き入れることもできる。例え ば研究者らは、デジタルカメラ用撮像チッ プの 1 つ 1 つの画素の上にホールアレイ を配置することで、入射してきた光をより 高い効率で捕らえられるようにする方法を 調べている。この方法が明らかになれば、 画素のノイズを軽減し、カメラの感度を高 めることができる。

プラズモンを利用して光をデバイスの中 に導き入れるもう 1 つの方法は、その表 面に金などの金属でできたナノサイズの粒 子をまくことである。これらのナノ粒子は、 整列した微小なアンテナ群のような働きを する。入射してきた光はプラズモンによっ て取り込まれ、向きを変えてデバイスの中 ヘと入っていく。

\section{太陽電池のスリム化}

商業的な視点からは、ナノアンテナ（実際 にはホールアレイ）の応用分野として最も 有力なのは太陽電池の改良である。今日 の太陽電池はシリコンなどの半導体からで きている。しかし、極めて広い範囲の波長 からできるだけ多くの光（特にスペクトル の赤から赤外域にかけての光）を捕らえる ためには、半導体層を厚くする必要があ る。オランダ・アムステルダムの AMOLF 研究所所長で、太陽電池のデザインの改 良に取り組んでいるフォトニクス研究者の Albert Polman は、「現在、シリコン太陽 電池の厚さは $300 \mu \mathrm{m}$ もあるのです」と いう。多数の太陽電池を屋根などに敷き 詰めるためには、高価なシリコンが大量に 必要になるため、費用がかさむ。ここで、 シリコン太陽電池の厚さを $1 \mu \mathrm{m}$ にするこ とができれば、価格は大幅に下がるだろう。 「けれどもこの厚さでは、赤い光はチップ の中をそのまま通り抜けてしまい、捕まえ ることができません」と彼はいう。そのた
め、太陽光のエネルギーの多くが無駄に なってしまう。同じ問題は、シリコン以外 の太陽電池材料にもあてはまる。

しかし、プラズモニクスにはこの問題が ない。現在研究されているアプローチの 1 つでは、表面の金ナノ粒子を半導体に 光を集中させるための反射鏡として利用す る。ここで、光が集中するほど吸収効率 は高くなる。もう１つのアプローチでは、 金のナノアンテナを使って光の進路を 90 度曲げることにより、光が半導体をまっす ぐに通り抜ける代わりに、その内部を伝 播するようにする。いずれの方法でも、太 陽電池の半導体層をはるかに薄くすること ができる。

プラズモンの技術は、太陽電池の製造 コストを下げるだけでなく、太陽光からエ ネルギーを取り出す効率を大幅に改善す ることができる。効率がほんの数％向上 しただけで大喜びしているこの分野では、 これは重要なことである。Atwater は米 国カリフォルニア州サンタクララの Alta
のライス大学の生物医学工学 者 Naomi Halas は、光学技 術を利用してがん細胞を破壊 したいと考えている。彼女は、 がん患者に金ナノ粒子を注射 し、粒子の表面に結合した抗 体によってこれを腫瘍まで導く ことを考えている。ナノ粒子が 目標部位に到達したら、この 領域に低出力の赤外レーザー を照射する。レーザーは健康 な組織には害をなさないが、 金ナノ粒子に吸収されてその 内部にプラズモンを生成する。 このエネルギーがナノ粒子を 高温にして、がん細胞を殺す という仕組みである ${ }^{11}$

Halas のがん治療法は、マ ウスを使った臨床試験ではうま くいっており、腫瘍をほぼ完全 に除去できたようにみえた。こ
の治療法は現在、人間での臨 床試験に入っており、頭頸部 がんの患者に対して行われて いる。Halas によると、今のと ころ非常に有望そうな結果が

出ているという。「人間での臨 床試験が、動物での臨床試験 よりも複雑になると考える理由 はありません。ここで細胞死を 誘発するために使っているの

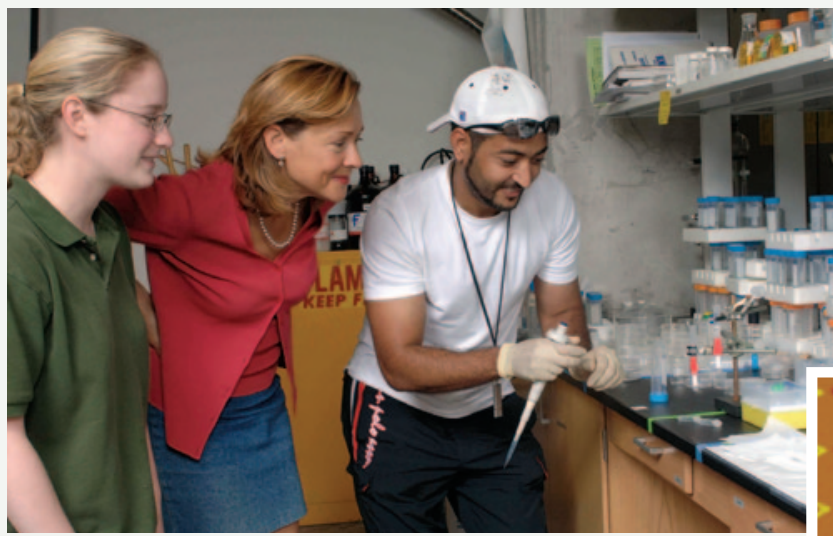

上 : Naomi Halas（中）は、プラズモンをがんの治療に役立てた いと考えている。右： 1 個の分子を検知するセンサーとしてプラズ モンを利用したいと考えている研究者もいる。
は、光と熱という物理的機構 であるからです」 Halas はま た、この治療法は新薬よりも 早く認可されるだろうと考えて いる。薬物の臨床試験は困難 で費用もかかり、医療現場で 実際に使用されるようになるま でには長い時間がかかる。彼 女によると、米国食品医薬品局 (FDA) はこの治療法を「薬 物」ではなく「装置」として 考えているため、認可の時期 はさらに早まるだろうという。

J.H.

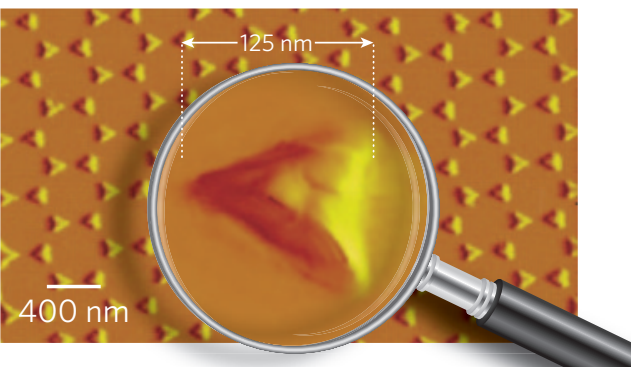


Devices 社の共同設立者としてこうした太 陽電池の商品化に取り組んでいるが、プ ラズモニクスを用いることで吸収量を全体 として $2 〜 5$ 倍にすることができたとい う。現時点ではアモルファスシリコン太陽 電池の効率は約 10 ～12\% であるが、増 強効果により約 17\% にすることができる と予想されている。また、現時点での効 率が約 $20 \%$ に達している結晶シリコン太 陽電池については、理論的最大值である 29\%にに近いところまでいけると考えられて いる。商品化に向けて残された課題として は、実際に使えるデバイスを設計すること や、大量生産のための製造技術を開発す ることなどがある。

光を導き、光コンピューターへ

プラズモニクス研究者は、より長期的な課 題にも取り組んでいる。それは、光デバイ スと電子デバイスを 1 つのマイクロチップ 上に集積化することである。数十年前から 考えられているのは、光を使うことにより、 従来の集積回路よりも多数のチャネル上 で、より高速に、チップ上の情報伝送を行 う光デバイスだ。これは、光ファイバーケー ブルが銅線よりもはるかに多くの情報を伝 送できるのと同じことである。しかし、こ れまでに実験的に製作された光学装置は 大きすぎ、光の信号強度の損失がかなり 大きかった。

「光学装置をトランジスタに近い大きさ にしていきたいのです」とPolman はいう。 そこでプラズモニクスの出番となり、これ を利用することで、最新のマイクロチップ のシリコン構造体とほぼ同じサイズの光経 路を作製することができる。「金属は、チッ プのデザインにうまく組み込むことができ ます」とPolman はいう。「そうすれば、 プラズモンにより集積回路の全体に光を 分配することができるでしょう」。実際、銀 のナノワイヤーのような構造体 ${ }^{2}$ または金 属表面に刻まれた溝 ${ }^{3}$ は、設計者の求め に応じてチップ中のあらゆる方向に光を導 く経路となることができる。
しかし、構造体を小さくすることで失わ れるものもある。プラズモン集積回路に関 するヨーロッパの研究プロジェクトのリー ダーであるオーデンセの南デンマーク大学 の Sergey Bozhevolnyi によると、プラズ モンが通るチャネルが狭すぎると、プラズ モンがその側面から漏れて失われてしまう のだという。それでも研究者らは、今の 世代のマイクロチップの約 1000 倍に相 当する $100 \mu \mathrm{m}$ 上の距離にわたって表面 プラズモンを導くことに成功している。こ の距離は、複雑な経路に沿って光を導き、 多くの処理段階を経て情報を運ぶ「プラ ズモンナノ回路」の豊かな可能性を期待 するのに十分な長さだ。

チップ上に光源（典型的にはレーザー） も組み込めるなら、プラズモン導波路へ の期待はさらに高まる。これは、レーザー 光の波長サイズの、比較的大きなレーザー を使って行われてきた。けれども今や、プ ラズモニクスにより、この波長よりもはる かに短いナノスケールの長さでそれを行え る可能性が出てきた。従来のレーザー空 洞内で光を増幅する代わりに、プラズモン の「スペーザー」が、プラズモンの助け を借りて光を増幅するのである。今年の 8 月には、こうしたプラズモンに基づくレー ザー発振の最初の実験的証拠が報告され た ${ }^{4,5}$ 。しかし、プラズモンレーザーを標 準的な超小型回路に完全に組み込むため には、研究者は標準的な電流を使ってス ペーザーをトリガーする方法を見つける必 要がある。

光学コンピューターを実現させるために は、光を発生させてチップ中に導くことに 加えて、プラズモンの流れのオン/オフを 高速で切り換えて、プラズモンの流れがデ ジタルデータストリームの一連のビットに なるような方法を開発する必要がある。多 くの研究者がそうした装置の開発に取り 組んできた。Atwater のグループは、シリ コン技術に基づくプラズモン变調素子を開 発した。電圧により微小電流を制御する 従来のトランジスタと同様、この種のデバ
イスは、電場を利用してデバイス中の表面 プラズモンの伝播を制御している ${ }^{6}$ 。プラ ズモン変調素子は、従来の光学变調素子 に比べて小さいだけでなく、その動作周 波数は容易に数十テラヘルツにすること ができる。これは、今日のコンピューター の数ギガヘルツという動作周波数とは桁 違いに大きい。

この技術の商業化については、シリコン との統合からデバイスの問題まで、多くの 障害が立ちはだかっている。スタンフォー ド大学（米国カリフォルニア州）の材料科 学者 Mark Brongersma は、「あらゆる段 階で問題になるのは金属中での損失です」 という。彼はまた、プラズモニック構造を 巧妙に設計することができれば、理論的 には、我慢できる程度まで損失を軽減する ことができるとも説明する。

プラズモニクス研究は過去 10 年間に長 足の進歩を遂げた。研究者らは今、金属 表面に非常に近いところでの物理過程の 理解など、プラズモンについての知識をさ らに深めようと努力している。それはとも かく、Atwaterは「過去 7、8 年間の出 来事をまとめると、プラズモニクスがフォ トニクスにナノスケールの世界に下りてく るカを与え、ナノサイエンスの仲間入りを させたということになります」とまとめて いる。（三枝小夜子 訳）

Joerg Heber は、Nature Materials のシニアエディター。

1. Ebbesen, T. W., Lezec, H. J., Ghaemi, H. F., Thio, T. \& Wolff, P. A. Nature 391, 667-669 (1998).

2. Verhagen, E., Spasenovi., M., Polman, A. \& Kuipers, L. Phys. Rev. Lett. 102, 203904 (2009).

3. Bozhevolnyi, S. I., Volkov, V. S., Devaux, E., Laluet, J.-Y. \& Ebbesen, T.W. Nature 440, 508-511(2006).

4. Noginov, M. A. et al. Nature 460, 1110-1112 (2009).

5. Oulton, R. F. et al. Nature 461, 629-632 (2009).

6. Dionne, J. A., Diest, K., Sweatlock, L. A. \& Atwater, H. A. Nano Lett. 9, 897-902 (2009).

7. Fleischmann, M., Hendra, P. J., McQuillan, A. J.Chem. Phys. Lett. 26, 163-166 (1974).

8. Jeanmaire, D. L. \& Van Duyne, R. P. J. Electroanal.Chem. 84, 1-20 (1977).

9. Nie, S. \& Emory, S. R. Science 275, 1102-1106 (1997).

10. Anker, J. N. et al. Nature Mater. 7, 442-453 (2008).

11. Hirsch, L. R.etal. Proc. NatlAcad. Sci. USA 100, 13549-13554 (2003). 